\title{
Role of adenosine in oligodendrocyte precursor maturation
}

\author{
Elisabetta Coppi ${ }^{1}$, Lucrezia Cellai $^{2}$, Giovanna Maraula ${ }^{2}$, Ilaria Dettori $^{2}$, Alessia Melani $^{2}$, \\ Anna Maria Pugliese ${ }^{2}$ and Felicita Pedata ${ }^{2 *}$
}

${ }^{1}$ Department of Health Sciences, University of Florence, Florence, Italy, ${ }^{2}$ Department NEUROFARBA, Division of Pharmacology and Toxicology, University of Florence, Florence, Italy

\section{OPEN ACCESS}

Edited by:

Fabio Blandini,

National Institute of Neurology C.

Mondino Foundation, Italy

Reviewed by:

Micaela Morelli,

University of Cagliari, Italy Hariharasubramanian Ramakrishnan,

State University of New York, USA

*Correspondence: Felicita Pedata, Department NEUROFARBA, Division of Pharmacology and Toxicology, University of Florence, Viale Pieraccini 6, 50132 Florence, Italy felicita.pedata@unifi.it

Received: 24 February 2015 Paper pending published: 17 March 2015

Accepted: 07 April 2015

Published: 24 April 2015

Citation:

Coppi E, Cellai L, Maraula G, Dettori I, Melani A, Pugliese AM and Pedata

$F(2015)$ Role of adenosine in oligodendrocyte precursor maturation.

Front. Cell. Neurosci. 9:155. doi: 10.3389/fncel.2015.00155
Differentiation and maturation of oligodendroglial cells are postnatal processes that involve specific morphological changes correlated with the expression of stage-specific surface antigens and functional voltage-gated ion channels. A small fraction of oligodendrocyte progenitor cells (OPCs) generated during development are maintained in an immature and slowly proliferative or quiescent state in the adult central nervous system (CNS) representing an endogenous reservoir of immature cells. Adenosine receptors are expressed by OPCs and a key role of adenosine in oligodendrocyte maturation has been recently recognized. As evaluated on OPC cultures, adenosine, by stimulating $A_{1}$ receptors, promotes oligodendrocyte maturation and inhibits their proliferation; on the contrary, by stimulating $A_{2 A}$ receptors, it inhibits oligodendrocyte maturation. $A_{1}$ and $A_{2 A}$ receptor-mediated effects are related to opposite modifications of outward delayed rectifying membrane $\mathrm{K}^{+}$currents $\left(I_{K}\right)$ that are involved in the regulation of oligodendrocyte differentiation. Brain $A_{1}$ and $A_{2 A}$ receptors might represent new molecular targets for drugs useful in demyelinating pathologies, such as multiple sclerosis (MS), stroke and brain trauma.

Keywords: oligodendrocyte progenitor cells, adenosine $A_{1}$ receptors, adenosine $A_{2 A}$ receptors, cell differentiation, outward $\mathrm{K}^{+}$currents

\section{Oligodendrocyte Differentiation During Embryonic Development}

Oligodendrocytes are neuroglial cells responsible, within the central nervous system (CNS), for myelin sheath formation that provides an electric isolation of axons and accelerates the transmission of electric signals. In order to become able to produce myelin, oligodendroglial cells progress through a series of highly regulated steps of differentiation from OPCs to mature oligodendrocytes (OLGs; Barateiro and Fernandes, 2014). OPCs are generated during embryonic development in restricted areas, such as the subventricular zone (SVZ) and present an amazing migratory ability that allow them to spread and populate brain and spinal cord (El Waly et al., 2014). They are the last cells to be generated after neurons and astrocytes. Their differentiation and maturation are postnatal processes. At the second postnatal day, rodents (rat and mouse) present mainly pre-oligodendrocytes and myelination of the CNS starts only at the seventh postnatal day (Dean et al., 2011). During their maturation, oligodendroglial cells lose their ability to migrate and proliferate (Barateiro and Fernandes, 2014) and acquire an elaborate morphology with many branched processes that wrap around axons and form membrane sheaths of myelin, typical of mature OLGs (de Castro and Bribián, 2005; Table 1). 
TABLE 1 | Antigenic pattern typical of the different steps of oligodendrocyte differentiation.

\begin{tabular}{|c|c|c|c|}
\hline $\begin{array}{l}\text { Oligodendrocyte } \\
\text { progenitor cell: OPC }\end{array}$ & $\begin{array}{l}\text { Pre-oligodendrocyte: } \\
\text { pre-OLG }\end{array}$ & $\begin{array}{c}\text { Immature } \\
\text { OLG }\end{array}$ & $\begin{array}{c}\text { Mature } \\
\text { OLG }\end{array}$ \\
\hline Nestin $^{+}$ & PDGFR $\alpha^{+}$ & $\mathrm{O}^{+}$ & $\mathrm{RIP}^{+}$ \\
\hline PDGFR $\alpha^{+}$ & $\mathrm{A}^{2} \mathrm{~B}^{+}$ & $\mathrm{RIP}^{+}$ & $\mathrm{GalC}^{+}$ \\
\hline $\mathrm{A}^{2} \mathrm{~B}^{+}$ & $\mathrm{NG} / \mathrm{AN}^{+}{ }^{+}$ & $\mathrm{GalC}^{+}$ & $\mathrm{CNP}^{+}$ \\
\hline $\mathrm{NG}_{2} / \mathrm{AN}^{+}{ }^{+}$ & $\mathrm{GD}^{+}$ & $\mathrm{CNP}^{+}$ & $\mathrm{MBP}^{+}$ \\
\hline $\mathrm{GD}^{+}$ & PLP DM20+ & & $\mathrm{PLP}^{+}$ \\
\hline PLP DM20+ & $\mathrm{O}^{+}$ & & $\mathrm{MAG}^{+}$ \\
\hline Olig2+ $^{+}$ & $\mathrm{CNP}^{+}$ & & \\
\hline
\end{tabular}

Oligodendrocyte maturation involves a sequence of distinct phases that can be identified by the expression of stagespecific surface antigens (Table 1) and by morphological changes (Sommer and Schachner, 1981; Raff et al., 1983; Goldman et al., 1984; Levi et al., 1986; Gard and Pfeiffer, 1990; Warrington and Pfeiffer, 1992; Gallo and Armstrong, 1995; Jung et al., 1996). These characteristics allow for a classification into four stages of differentiation: OPC, pre-oligodendrocyte (pre-OLG), immature oligodendrocyte and mature myelinating oligodendrocyte (OLG; Szuchet et al., 2011; Barateiro and Fernandes, 2014). The initial stage of maturation, as seen at 1-2 days in culture, presents a bipolar (or tripolar) morphology, typical of OPCs (Coppi et al., 2013a). Several are the markers of precocious maturation stages, such as platelet-derived growth factor receptor $\alpha(\operatorname{PDGFR} \alpha)$, chondroitin sulfate proteoglycan nerve-glial antigen 2 (NG2) or the transcription factor Olig2 (Pringle et al., 1992; Nishiyama et al., 1996; Ligon et al., 2006). When OPCs start to differentiate in pre-OLGs, they are characterized by emerging secondary ramifications and by the expression of different antigens such as O4 (Sommer and Schachner, 1981). Then they acquire the typical phenotype of immature OLGs characterized by a complex multipolar morphology (Back et al., 2001). At this stage, the expression of markers typical of intermediate steps of maturation, such as O4, persists while markers of the earlier stage such as NG2 and PDGFR $\alpha$ are down regulated (Yu et al., 1994). Finally, when OLGs reach the mature myelinating stage, they acquire highly ramified morphology and immunoreactivity for myelin specific structural proteins such as MAG (myelin associated glycoprotein) and MBP (myelin basic protein) (Scolding et al., 1989; Zhang, 2001). OLGs synthesize large amounts of myelin, giving rise to multilamellar myelin sheath that wrap and isolate neuronal axons.

During their maturation, oligodendrocyte lineage cells display different functional voltage-gated ion channels (Sontheimer et al., 1989) including both inward and outward rectifying $\mathrm{K}^{+}$channels (Sontheimer and Kettenmann, 1988; Williamson et al., 1997), $\mathrm{Na}^{+}$channels (Barres et al., 1990; Berger et al., 1992), and different subtype of $\mathrm{Ca}^{2+}$ channels (Verkhratsky et al., 1990; Berger et al., 1992). OPCs $\left(\mathrm{NG}^{+}\right)$show outward membrane currents whose main component is represented by delayed rectifying $\mathrm{K}^{+}$currents $\left(\mathrm{I}_{\mathrm{K}}\right)$ (Gallo et al., 1996) characterized by low time- and voltage-dependent inactivation and by a threshold of activation at about $-40 \mathrm{mV}$. On the contrary, the transient outward current $\left(\mathrm{I}_{\mathrm{A}}\right)$, another $\mathrm{K}^{+}$ conductance typical of undifferentiated OPCs, presents a rapid time-dependent inactivation (approximately $50 \mathrm{~ms}$ ) and a voltage-dependent inactivation at potentials above $-40 \mathrm{mV}$ (Gallo et al., 1996). At this immature stage a subpopulation (about 60\%) of OPCs also possess an inward, tetrodotoxinsensitive, $\mathrm{Na}^{+}$current $\left(\mathrm{I}_{\mathrm{Na}}\right)$ characterized by a rapid timedependent inactivation (less than $1 \mathrm{~ms}$ ) and by a peak of amplitude evoked at about $-10 \mathrm{mV}$ (Káradóttir et al., 2008). $\mathrm{I}_{\mathrm{Na}}$ is never observed in mature oligodendroglial stages (Coppi et al., 2013a).

During development, membrane outward $\mathrm{K}^{+}$conductances (both $\mathrm{I}_{\mathrm{K}}$ and $\mathrm{I}_{\mathrm{A}}$ ) undergo a strong down regulation up to almost completely disappear in mature OLGs (Sontheimer et al., 1989; Barres et al., 1990; Gallo et al., 1996; Attali et al., 1997; Coppi et al., 2013a).

In parallel with outward $\mathrm{K}^{+}$current downregulation, there is a gradual increase in the expression of inwardly rectifying $\mathrm{K}^{+}$currents $\left(\mathrm{K}_{\mathrm{ir}}\right)$, activated at potentials more negative than membrane resting potential $(\mathrm{Vm}$, about $-70 \mathrm{mV}) . \mathrm{K}_{\mathrm{ir}}$ currents are the main conductance represented in mature OLGs (Knutson et al., 1997).

Among the mentioned currents, voltage-gated $\mathrm{K}^{+}$currents, such as $\mathrm{I}_{\mathrm{K}}, \mathrm{I}_{\mathrm{A}}$ and $\mathrm{K}_{\mathrm{ir}}$, are involved in the regulation of oligodendrocyte differentiation and thus of myelin formation (Sontheimer et al., 1989; Gallo et al., 1996). In addition, the expression of $\mathrm{I}_{\mathrm{K}}$ currents is linked to cell cycle regulation and hence to proliferative capacity of OPCs (Chittajallu et al., 2005) because of the following: (1) a down regulation of $I_{K}$ occurs as oligodendrocyte lineage cells mature (Sontheimer et al., 1989; Barres et al., 1990); (2) proliferative OPCs express larger $\mathrm{I}_{\mathrm{K}}$ currents than cell cycle-arrested OPCs (Knutson et al., 1997; Chittajallu et al., 2002); and (3) pharmacological block of $\mathrm{I}_{\mathrm{K}}$ induced by tetra-ethyl-ammonium (TEA) in cells belonging to the oligodendrocyte lineage is sufficient to delay their proliferation and differentiation (Gallo et al., 1996; Chittajallu et al., 2002). Hence, treatments aimed at modulating these currents may affect oligodendrocyte proliferation and differentiation.

\section{Adult Oligodendrocyte Progenitor Cells}

It has been demonstrated that a small fraction of OPCs generated during development are maintained in an immature and slowly proliferative or quiescent state in the adult CNS (Dawson et al., 2003) where they are called "adult OPCs". Adult OPCs are present in all brain structures where they represent the 2-9\% of the total cellular population of the CNS (Dawson et al., 2003) thus being the largest population of proliferating cells within the CNS (Horner et al., 2000). Adult OPCs persists stable in the adult CNS (Rivers et al., 2008) where they represent an endogenous reservoir of immature cells (de Castro and Bribián, 2005), constantly produced by neural stem cells located in the SVZ (Menn et al., 2006). Current evidence suggests that adult OPCs express the same markers (e.g., NG2 or PDGFR $\alpha$ ) and appear morphologically similar to their developmental counterpart (Franklin and Ffrench-Constant, 2008). 
Very little is known about factors that control adult oligodendrogenesis. Upon opportune physiological (e.g., voluntary physical exercise; Simon et al., 2011) or pathological (e.g., injury, inflammation, demyelination) stimuli, adult OPCs are able to react with increased proliferation and subsequent differentiation in mature OLGs (Simon et al., 2011), thus representing the primary source of myelinating cells in the CNS (Nishiyama et al., 1999; Windrem et al., 2004).

Self-renewal and multipotency features of adult OPCs have been reported. Thanks to their self-renewal features, adult OPCs continue to proliferate throughout life span (Young et al., 2013) and to differentiate into mature OLGs, ensuring myelin integrity. Under specific conditions, adult OPCs give rise to neurons, astrocytes (Nishiyama et al., 2009) and Schwann cells (Zawadzka et al., 2010). However, multipotency of adult OPCs is still to be confirmed since remains controversial due to some discrepancy between in vitro and in vivo data (Crawford et al., 2014).

Adult OPCs have been shown to contact the axonal membrane (Butt et al., 1999) and the synaptic terminals (Ong and Levine, 1999). This raises the question of whether adult OPCs may be capable to impact or to react to neuronal activity (Butt et al., 2002, 2005; Nishiyama et al., 2002). Concerning this topic a recent study demonstrated the positive impact of neuronal activity on myelination in the adult brain (Gibson et al., 2014).

\section{Adenosine and Oligodendrocyte Maturation}

It is known that purines, in addition to their functions as neurotransmitters and neuromodulators, can also act as growth and trophic factors, thus influencing the development of neuronal (Mishra et al., 2006; Migita et al., 2008) and glial (Stevens and Fields, 2000; Stevens et al., 2002) cells.

All adenosine receptor subtypes $\left(A_{1}, A_{2 A}, A_{2 B}, A_{3}\right)$ are expressed on different cell types within the CNS including oligodendrocytes, likely being able to modulate cell-to-cell communication between neurons and glial cells (Othman et al., 2003; Agresti et al., 2005).

The expression by oligodendrocytes of the equilibrative nucleoside transporters ENT1 and ENT2, as well as adenosine degrading enzymes such as adenosine deaminase and adenosine kinase has been demonstrated (González-Fernández et al., 2014). All adenosine receptor subtypes are also expressed by OPCs (Stevens et al., 2002; Fredholm et al., 2011) and a key role of adenosine in oligodendrocyte maturation has been recognized (Burnstock et al., 2011). In particular it was demonstrated that adenosine can affect numerous OPC processes such as migration, proliferation and maturation (Stevens and Fields, 2000; Stevens et al., 2002; Coppi et al., 2013a).

\section{Adenosine $A_{1}$ Receptor-Mediated Effects on Oligodendrogenesis}

Treatment of cultured OPCs with adenosine exerts a concentration-dependent reduction of their proliferation in the presence of the mitogen PDGF and promotes cell differentiation towards pre-myelinating oligodendrocytes, an effect that is mediated by $A_{1}$ receptor (Stevens et al., 2002). A chronic adenosine treatment in co-cultures of OPCs with dorsal root ganglion neurons also promotes myelination as shown by the rise of $\mathrm{MBP}^{+}$cells after 14 days (Stevens et al., 2002). Of note, the percentage of myelinating $\mathrm{MBP}^{+}$ OLGs was lower in co-cultures treated with the adenosine receptor antagonist, suggesting that endogenous sources of adenosine are sufficient to promote OPC differentiation (Stevens et al., 2002). In addition, the activation of $A_{1}$ receptor has been reported to induce OPC migration (Othman et al., 2003).

On these basis, it was proposed that activation of $A_{1}$ receptors on OPCs by extracellular adenosine allows for the beginning of the myelination process possibly offering new approaches for the treatment of demyelinating diseases in the CNS, such as MS (Stevens et al., 2002).

Such an effect, however, is different from what has been described in neonatal rats. Neonatal rats treated with $\mathrm{A}_{1}$ receptor agonists showed a marked reduction in white and gray matter volume and ventriculomegaly (Turner et al., 2002) with reduced expression of MBP similarly to what observed in neonatal rats reared in hypoxia (Ment et al., 1998). Ventriculomegaly was also observed in mice lacking the enzyme adenosine deaminase which degrades adenosine (Turner et al., 2003). Moreover, hypoxia-induced periventricular white matter injury (PWMI, a form of brain injury sustained by preterm infants) was prevented in mice lacking $A_{1}$ receptor (Turner et al., 2003). These data support the notion that adenosine, acting on $A_{1}$ receptor, mediates hypoxia-induced brain injury and ventriculomegaly during early postnatal development (Turner et al., 2003). Such effect could be attributed to the fact that adenosine released under hypoxia and acting on $A_{1}$ receptors leads to premature differentiation and reduced proliferation of oligodendroglia precursors. In fact, studies of OPCs and preOLGs in hypoxic conditions revealed a reduced proliferation and an accelerated maturation, as demonstrated by the increased expression of the cell cycle regulatory proteins p27 (Kip1) and phospho-cdc2 (Akundi and Rivkees, 2009). This series of events would lead to a reduced number of OLGs available for myelination, thus contributing to PWMI (see in Rivkees and Wendler, 2011). Thus, strategies aimed at stimulating OPC proliferation in neonatal hypoxia/ischemia may be of value to prevent PWMI.

\section{Adenosine $A_{2 A}$ Receptor-Mediated Effects on Oligodendrogenesis}

The first functional characterization of adenosine $\mathrm{A}_{2 \mathrm{~A}}$ receptors in OPCs has been recently reported (Coppi et al., 2013b). It was demonstrated that the selective $\mathrm{A}_{2 \mathrm{~A}}$ receptor agonist CGS21680 inhibits $\mathrm{I}_{\mathrm{K}}$ currents in cultured OPCs with an $\mathrm{EC}_{50}$ in the low nanomolar range (which is in line with values reported in the literature: see Jarvis et al., 1989; Fredholm et al., 2011). Furthermore, CGS21680 inhibits in vitro OPC differentiation since it increases the percentage of $\mathrm{NG}^{+}$ immature OPCs and reduces $\mathrm{O}^{+}$pre-OLGs and $\mathrm{MAG}^{+}$ mature OLGs, without affecting neither cell viability nor cell proliferation (Coppi et al., 2013b). These effects are completely 
prevented in the presence of the selective $\mathrm{A}_{2 \mathrm{~A}}$ receptor antagonist SCH58261. TEA, at concentrations that block $\mathrm{I}_{\mathrm{K}}$ but not $\mathrm{I}_{\mathrm{A}}$ currents, mimics and occludes the effect of the $A_{2 A}$ agonist on membrane currents, confirming a selective modulation by this purinergic receptor subtype of $\mathrm{I}_{\mathrm{K}}$ currents (Coppi et al., 2013b). Similar effects mediated by $\mathrm{A}_{2 \mathrm{~A}}$ receptors on outward rectifying $\mathrm{K}^{+}$channels have already been described in other cell types (Xu and Enyeart, 1999; Duffy et al., 2007), with an involvement of either intracellular cAMP rise or a direct action of the $G$ s protein coupled to $A_{2 A}$ receptors being hypothesized. Of note, we have demonstrated that the activation of GPR17, a recently deorphanized Gi-coupled P2Ylike receptor, which stimulates OPC differentiation (Lecca et al., 2008; Fumagalli et al., 2011), elicits opposite effects in comparison to the Gs coupled $\mathrm{A}_{2 \mathrm{~A}}$ subtype, thus increasing the amplitude of $\mathrm{I}_{\mathrm{K}}$ currents recorded from cultured OPCs (Coppi et al., 2013a). Increased amplitude of $\mathrm{I}_{\mathrm{K}}$ currents is obtained also by selective stimulation of adenosine, Gi-coupled, $A_{1}$ receptors (unpublished observation mentioned in Coppi et al. (2013b)). Taken together, these data suggest that the intracellular signaling pathway leading to cAMP decrease in OPC cultures are positively coupled to $\mathrm{I}_{\mathrm{K}}$ currents and cell differentiation (Figure 1B).

In keeping with data demonstrating that the inhibition of $\mathrm{I}_{\mathrm{K}}$ currents impairs proliferation and maturation of cultured OPCs (Gallo et al., 1996; Attali et al., 1997; Ghiani et al., 1999; Chittajallu et al., 2002; Vautier et al., 2004) and blocks myelin deposition in embryonic spinal cord (Shrager and Novakovic, 1995), it appears that $\mathrm{A}_{2 \mathrm{~A}}$ receptor stimulation inhibits OPC differentiation by reducing $\mathrm{I}_{\mathrm{K}}$ currents (Figure 1A). In line with this assumption, it has been observed that adenosine $A_{1}$ receptors, which enhances $\mathrm{I}_{\mathrm{K}}$ currents in OPCs, exert a pro-differentiating effect in oligodendrocyte cultures (Stevens et al., 2002; Figure 1B). However, we cannot exclude that other intracellular pathways, in addition to $I_{K}$ current block, contribute to the $A_{2 A}$ receptormediated inhibition of OPC differentiation. In OPCs, the tyrosine kinase fibroblast growth factor receptor (FGF) is also expressed and its activation promotes cell proliferation and inhibits the expression of myelin components (Besnard et al., 1989). On the contrary, the simultaneous activation of both $\mathrm{A}_{2 \mathrm{~A}}$ and FGF receptors, by robust activation of the mitogen activated protein kinase (MAPK/ERK) pathway, brings to differentiation and neurite extension of PC12 cells (Flajolet et al., 2008). It is likely that also in OPCs a cross talk between the two receptors regulates cell maturation.

Upregulation of $\mathrm{A}_{2 \mathrm{~A}}$ receptor has been observed in cerebral white matter of patients with secondary progressive MS: higher density of brain $\mathrm{A}_{2 \mathrm{~A}}$ receptor appeared correlated with higher disability scale scores in MS patients (Rissanen et al., 2013). These data were interpreted as $\mathrm{A}_{2 \mathrm{~A}}$ receptor upregulation on brain cells is associated with the disease progression. In agreement, in a mouse model of experimental autoimmune encephalomyelitis (EAE: an animal model for MS), adenosine $\mathrm{A}_{2 \mathrm{~A}}$ antagonists protected from disease development (Mills et al., 2012), suggesting that activation of adenosine $A_{2 A}$ receptors on neuronal and glial cells is responsible for EAE development in mice. Moreover in a rat model of focal brain ischemia (the middle cerebral artery occlusion: MCAO model), adenosine $A_{2 A}$ receptor antagonists systemically administered after ischemia prevented the activation of JNK mitogen activated kinase (Melani et al., 2009) that, by activating caspase 3 and the pro-apoptotic regulator DP5 (Yin et al., 2005), is involved in oligodendrocyte cell death (Howe et al., 2004; Jurewicz et al., 2006). Selective $A_{2 A}$ adenosine antagonists also prevented the myelin disorganization in the basal nuclei and reduced the expression of Olig2 (Melani et al., 2009), a marker of immature OPCs, poorly expressed by mature OLGs.

In light of these data, it can be postulated that, under demyelinating conditions, the $\mathrm{A}_{2 \mathrm{~A}}$ receptor-mediated inhibition of OPC maturation is associated with an increased damage, since the stimulation of this receptor subtype prevents myelin deposition.

Such a role of adenosine $A_{2 A}$ receptor might appear in contrast with the observation that genetic ablation of both central and peripheral $\mathrm{A}_{2 \mathrm{~A}}$ receptors exacerbates brain damage and neuroinflammation in a mouse model of EAE (Yao et al., 2012). In fact, $A_{2 A}$ receptors on peripheral leucocytes are known to reduce adhesion cell factor production and neutrophil activation (Sitkovsky et al., 2004). Thus, it is likely that genetic ablation of adenosine $\mathrm{A}_{2 \mathrm{~A}}$ receptor on blood cells is crucial in exacerbating leucocyte infiltration, neuroinflammation and brain damage in a model of chronic inflammation such as EAE (see Pedata et al., 2014). A regulation of neuroinflammation by adenosine receptors might be critical in the modulation of myelin repair mechanisms in different neurodegenerative diseases affecting the CNS.

\section{Effect of Caffeine on the White Matter Injury in Hypoxic Neonatal Brain}

Caffeine is widely used in neonatal medicine in order to stimulate the respiration in premature infants. Apnea of prematurity (AOP) is a significant clinical problem manifested by an unstable respiratory rhythm reflecting the immaturity of respiratory control systems. AOP typically resolves with maturation suggesting that increased myelination of the brainstem is required for disease remission (Mathew, 2011). This raises the question of whether caffeine improves the myelination and therefore the immaturity of respiratory control systems.

In hypoxia-exposed neonatal mice pups treated with caffeine, myelination was enhanced and ventriculomegaly reduced from postnatal days 3 through 12; furthermore, more normally arranged myelinated axon orientation than that observed in hypoxia was reported (Back et al., 2006). Caffeine also increased the percentage of immature OLGs in the brain tissue (Back et al., 2006). Further support for the notion that caffeine is neuroprotective in development is provided by non-randomized studies demonstrating that improved myelination is observed in premature baboons treated with caffeine (Loeliger et al., 2006).

Caffeine is a non-selective antagonist of $A_{1}$ and $A_{2 A}$ receptors, thus increased myelination could be ascribed to the inhibition of one or both $A_{1}$ and $A_{2 A}$ receptor subtype. Since adenosine 


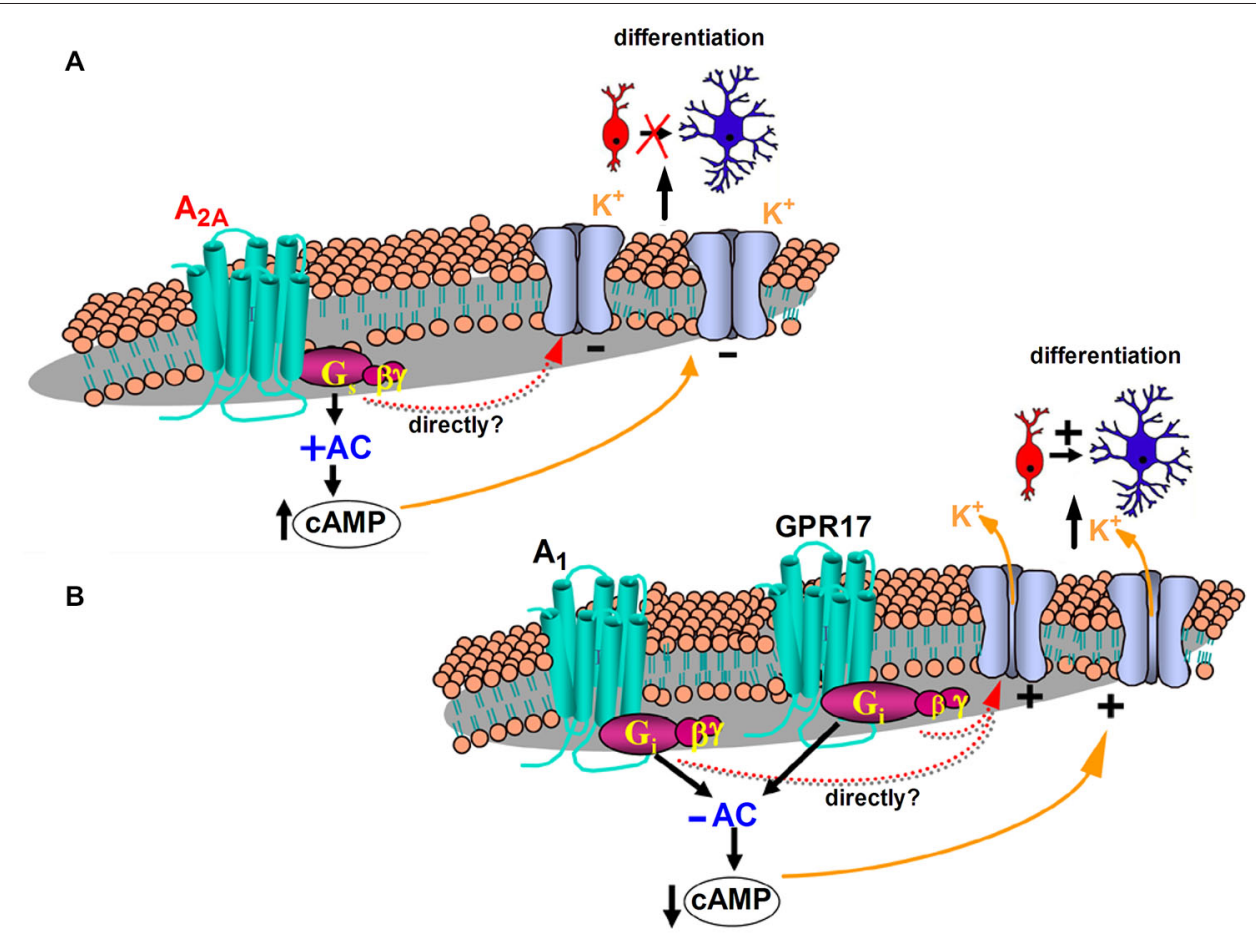

FIGURE 1 | Proposed mechanisms underlying $\mathrm{K}^{+}$channel modulation and differentiation of oligodendrocyte progenitor cells (OPCs: red cells) into mature oligodendrocytes (blue cells) after purinergic receptor activation. (A) Stimulation of the Gs coupled adenosine $A_{2 A}$ receptor subtype increases adenyl cyclase (AC) activity and intracellular cyclic adenosine monophosphate (CAMP), decreases the amplitude of $I_{K}$ currents recorded from cultured OPCs and inhibits OPC differentiation (Coppi et al., 2013b). (B) The

Gi-coupled adenosine $A_{1}$ receptor decreases AC activity and intracellular CAMP, increases the amplitude of $I_{k}$ currents recorded from cultured OPCs (Coppi et al., 2013b) and promotes OPCs to more mature stages of differentiation (Stevens et al., 2002). Increased amplitude of $I_{K}$ currents is obtained also by selective stimulation of GPR17 (Coppi et al., 2013a), a recently deorphanized Gi-coupled P2Y-like receptor, which decreases AC activity and intracellular cAMP and stimulates OPC maturation (Lecca et al., 2008; Fumagalli et al., 2011). Modulation of $I_{K}$ currents may be directly driven by G-protein subunit/s or indirectly through modulation of intracellular CAMP levels.
$A_{1}$ receptors are causative of hypoxia-induced brain injury and ventriculomegaly during early postnatal development (Turner et al., 2002, 2003), antagonism of adenosine $A_{1}$ receptors is relevant in the action mechanism of caffeine.

\section{Conclusions}

As evaluated directly on cultured OPCs, adenosine acts as a dual modulator of OPC development since, by stimulating $A_{1}$ receptors, it promotes oligodendrocyte maturation and inhibits their proliferation (Stevens et al., 2002) and, on the contrary, by stimulating $\mathrm{A}_{2 \mathrm{~A}}$ receptors, it inhibits oligodendrocyte maturation (Coppi et al., 2013b).

Most probably, the effects of adenosine on OPC maturation are of relevance during demyelinating pathologies, such as MS, EAE or ischemia. However, it appears that a premature differentiation and reduced proliferation of OPCs might

\section{References}

Agresti, C., Meomartini, M. E., Amadio, S., Ambrosini, E., Serafini, B., Franchini, L., et al. (2005). Metabotropic P2 receptor activation regulates oligodendrocyte progenitor migration and development. Glia 50, 132-144. doi: 10.1002/glia. 20160 compromise the process of myelination as in PWMI in preterm infants. The outcome of stimulation of adenosine $A_{1}$ and $A_{2 A}$ receptors on myelination depends likely on the timing of their stimulation during the development and on the different demyelinating pathologies.

Identification of critical regulators that inhibit myelination/remyelination could facilitate the development of therapeutic targets for myelin repair in CNS demyelinating diseases. For example, the fact that in MS lesions OPCs are present but fail to differentiate into mature OLGs (Levine and Reynolds, 1999; Chang et al., 2000), suggests that the remyelination process is blocked at a premyelinating stage.

Adenosine $A_{1}$ and $A_{2}$ receptors (to date no investigations concerning the role of adenosine $\mathrm{A}_{3}$ or $\mathrm{A}_{2 \mathrm{~B}}$ receptors on OPC maturation have been performed) represent new possible molecular targets for drugs useful in demyelinating pathologies, such as MS, stroke and brain trauma. 
Back, S. A., Craig, A., Luo, N. L., Ren, J., Akundi, R. S., Ribeiro, I., et al. (2006). Protective effects of caffeine on chronic hypoxia-induced perinatal white matter injury. Ann. Neurol. 60, 696-705. doi: 10.1002/ana.21008

Back, S. A., Luo, N. L., Borenstein, N. S., Levine, J. M., Volpe, J. J., and Kinney, H. C. (2001). Late oligodendrocyte progenitors coincide with the developmental window of vulnerability for human perinatal white matter injury. J. Neurosci. 21, 1302-1312.

Barateiro, A., and Fernandes, A. (2014). Temporal oligodendrocyte lineage progression: in vitro models of proliferation, differentiation and myelination. Biochim. Biophys. Acta 1843, 1917-1929. doi: 10.1016/j.bbamcr.2014.04.018

Barres, B. A., Koroshetz, W. J., Swartz, K. J., Chun, L. L., and Corey, D. P. (1990). Ion channel expression by white matter glia: the O-2A glial progenitor cell. Neuron 4, 507-524. doi: 10.1016/0896-6273(90)90109-s

Berger, T., Schnitzer, J., Orkand, P. M., and Kettenmann, H. (1992). Sodium and calcium currents in glial cells of the mouse corpus callosum slice. Eur. J. Neurosci. 4, 1271-1284. doi: 10.1111/j.1460-9568.1992.tb00153.x

Besnard, F., Perraud, F., Sensenbrenner, M., and Labourdette, G. (1989). Effects of acidic and basic fibroblast growth factors on proliferation and maturation of cultured rat oligodendrocytes. Int. J. Dev. Neurosci. 7, 401-409. doi: 10. 1016/0736-5748(89)90061-0

Burnstock, G., Fredholm, B. B., and Verkhratsky, A. (2011). Adenosine and ATP receptors in the brain. Curr. Top. Med. Chem. 11, 973-1011. doi: 10. 2174/156802611795347627

Butt, A. M., Duncan, A., Hornby, M. F., Kirvell, S. L., Hunter, A., Levine, J. M., et al. (1999). Cells expressing the NG2 antigen contact nodes of Ranvier in adult CNS white matter. Glia 26, 84-91. doi: 10.1002/(sici)10981136(199903)26:1<84::aid-glia9>3.0.co;2-1

Butt, A. M., Hamilton, N., Hubbard, P., Pugh, M., and Ibrahim, M. (2005). Synantocytes: the fifth element. J. Anat. 207, 695-706. doi: 10.1111/j.1469-7580. 2005.00458.x

Butt, A. M., Kiff, J., Hubbard, P., and Berry, M. (2002). Synantocytes: new functions for novel NG2 expressing glia. J. Neurocytol. 31, 551-565. doi: 10. 1023/A:1025751900356

Chang, A., Nishiyama, A., Peterson, J., Prineas, J., and Trapp, B. D. (2000). NG2positive oligodendrocyte progenitor cells in adult human brain and multiple sclerosis lesions. J. Neurosci. 20, 6404-6412.

Chittajallu, R., Aguirre, A. A., and Gallo, V. (2005). Downregulation of platelet-derivedgrowth factor-alpha receptor-mediated tyrosine kinase activity as a cellular mechanisfor $\mathrm{K}^{+-}$channel regulation during oligodendrocyte development in situ. J. Neurosci. 25, 8601-8610. doi: 10.1523/jneurosci.212205.2005

Chittajallu, R., Chen, Y., Wang, H., Yuan, X., Ghiani, C. A., Heckman, T., et al. (2002). Regulation of Kv1 subunit expression in oligodendrocyte progenitor cells and their role in G1/S phase progression of the cell cycle. Proc. Natl. Acad. Sci. U S A 99, 2350-2355. doi: 10.1073/pnas.042698399

Coppi, E., Cellai, L., Maraula, G., Pugliese, A. M., and Pedata, F. (2013b). Adenosine $\mathrm{A}_{2 \mathrm{~A}}$ receptors inhibit delayed rectifier potassium currents and cell differentiation in primary purified oligodendrocyte cultures. Neuropharmacology 73, 301-310. doi: 10.1016/j.neuropharm.2013.05.035

Coppi, E., Maraula, G., Fumagalli, M., Failli, P., Cellai, L., Bonfanti, E., et al. (2013a). UDP-glucose enhances outward $\mathrm{K}^{+}$currents necessary for cell differentiation and stimulates cell migratory by activating the GPR17 receptors in oligodendrocyte precursors. Glia 61, 1155-1171. doi: 10.1002/glia.22506

Crawford, A. H., Stockley, J. H., Tripathi, R. B., Richardson, W. D., and Franklin, R. J. M. (2014). Oligodendrocyte progenitors: adult stem cells of the central nervous system? Exp. Neurol. 260, 50-55. doi: 10.1016/j.expneurol.2014. 04.027

Dawson, M. R., Polito, A., Levine, J. M., and Reynolds, R. (2003). NG2-expressing glial progenitor cells: an abundant and widespread population of cycling cells in the adult rat CNS. Mol. Cell Neurosci. 24, 476-488. doi: 10.1016/s10447431(03)00210-0

Dean, J. M., Moravec, M. D., Abend, N., Ren, J., Gong, X., Volpe, J. J., et al. (2011). Strain-specific differences in perinatal rodent oligodendrocyte lineage progression and its correlation with human. Dev. Neurosci. 33, 251-260. doi: 10. $1159 / 000327242$

de Castro, F., and Bribián, A. (2005). The molecular orchestra of the migration of oligodendrocyte precursors during development. Brain Res. Brain Res. Rev. 49, 227-241. doi: 10.1016/j.brainresrev.2004.12.034
Duffy, S. M., Cruse, G., Brightling, C. E., and Bradding, P. (2007). Adenosine closes the $\mathrm{K}^{+}$channel KCa3.1 in human lung mast cells and inhibits their migration via the adenosine $\mathrm{A}_{2 \mathrm{~A}}$ receptor. Eur. J. Immunol. 37, 1653-1662. doi: 10.1002/eji.200637024

El Waly, B., Macchi, M., Cayre, M., and Durbec, P. (2014). Oligodendrogenesis in the normal and pathological central nervous system. Front. Neurosci. 8:145. doi: 10.3389/fnins.2014.00145

Flajolet, M., Wang, Z., Futter, M., Shen, W., Nuangchamnong, N., Bendor, J., et al. (2008). FGF acts as a co-transmitter through adenosine $\mathrm{A}(2 \mathrm{~A})$ receptor to regulate synaptic plasticity. Nat. Neurosci. 11, 1402-1409. doi: 10.1038/nn. 2216

Franklin, R. J., and Ffrench-Constant, C. (2008). Remyelination in the CNS: from biology to therapy. Nat. Rev. Neurosci. 9, 839-855. doi: 10.1038/nrn2480

Fredholm, B. B., IJzerman, A. P., Jacobson, K. A., Linden, J., and Müller, C. E. (2011). International Union of basic and clinical pharmacology. LXXXI. Nomenclature and classification of adenosine receptors-an update. Pharmacol. Rev. 63, 1-34. doi: 10.1124/pr.110.003285

Fumagalli, M., Daniele, S., Lecca, D., Lee, P. R., Parravicini, C., Fields, R. D., et al. (2011). Phenotypic changes, signaling pathway and functional correlates of GPR17-expressing neural precursor cells during oligodendrocyte differentiation. J. Biol. Chem. 286, 10593-10604. doi: 10.1074/jbc.M110. 162867

Gallo, V., and Armstrong, R. C. (1995). Developmental and growth factor-induced regulation of nestin in oligodendrocyte lineage cells. J. Neurosci. 15(1 Pt. 1), 394-406.

Gallo, V., Zhou, J. M., McBain, C. J., Wright, P., Knutson, P. L., and Armstrong, R. C. (1996). Oligodendrocyte progenitor cell proliferation and lineage progression are regulated by glutamate receptor-mediated $\mathrm{K}^{+}$channel block. J. Neurosci. 16, 2659-2670.

Gard, A. L., and Pfeiffer, S. E. (1990). Two proliferative stages of the oligodendrocyte lineage (A2B5+O4- and O4+GalC-) under different mitogenic control. Neuron 5, 615-625. doi: 10.1016/0896-6273(90)90216-3

Ghiani, C. A., Yuan, X., Eisen, A. M., Knutson, P. L., DePinho, R. A., McBain, C. J., et al. (1999). Voltage-activated $\mathrm{K}^{+}$channels and membrane depolarization regulate accumulation of the cyclin-dependent kinase inhibitors p27(Kip1) and p21(CIP1) in glial progenitor cells. J. Neurosci. 19, 5380-5392.

Gibson, E. M., Purger, D., Mount, C. W., Goldstein, A. K., Lin, G. L., Wood, L. S., et al. (2014). Neuronal activity promotes oligodendrogenesis and adaptative myelination in the mammalian brain. Science 344:1252304. doi: 10 . $1126 /$ science. 1252304

Goldman, J. E., Hirano, M., Yu, R. K., and Seyfried, T. N. (1984). GD3 ganglioside is a glycolipid characteristic of immature neuroectodermal cells. J. Neuroimmunol. 7, 179-192. doi: 10.1016/s0165-5728(84)80017-x

González-Fernández, E., Sánchez-Gómez, M. V., Pérez-Samartín, A., Arellano, R. O., and Matute, C. (2014). A3 Adenosine receptors mediate oligodendrocyte death and ischemic damage to optic nerve. Glia 62, 199-216. doi: 10.1002/glia.22599

Horner, P. J., Power, A. E., Kempermann, G., Kuhn, H. G., Palmer, T. D., Winkler, J., et al. (2000). Proliferation and differentiation of progenitor cells throughout the intact adult rat spinal cord. J. Neurosci. 20, 2218-2228.

Howe, C. L., Bieber, A. J., Warrington, A. E., Pease, L. R., and Rodriguez, M. (2004). Antiapoptotic signaling by a remyelination-promoting human antimyelin antibody. Neurobiol. Dis. 15, 120-131. doi: 10.1016/j.nbd.2003.09.002

Jarvis, M. F., Schulz, R., Hutchison, A. J., Do, U. H., Sills, M. A., and Williams, M. (1989). [3H]CGS 21680, a selective $A_{2}$ adenosine receptor agonist directly labels $\mathrm{A}_{2}$ receptors in rat brain. J. Pharmacol. Exp. Ther. 251, 888-893.

Jung, M., Sommer, I., Schachner, M., and Nave, K. A. (1996). Monoclonal antibody O10 defines a conformationally sensitive cell-surface epitope of proteolipid protein (PLP): evidence that PLP misfolding underlies dysmyelination in mutant mice. J. Neurosci. 16, 7920-7929.

Jurewicz, A., Matysiak, M., Andrzejak, S., and Selmaj, K. (2006). TRAIL-induced death of human adult oligodendrocytes is mediated by JNK pathway. Glia 53, 158-166. doi: 10.1002/glia.20249

Káradóttir, R., Hamilton, N. B., Bakiri, Y., and Attwell, D. (2008). Spiking and nonspiking classes of oligodendrocyte precursor glia in CNS white matter. Nat. Neurosci. 11, 450-456. doi: 10.1038/nn2060

Knutson, P., Ghiani, C. A., Zhou, J. M., Gallo, V., and McBain, C. J. (1997). K ${ }^{+}$ channel expression and cell proliferation are regulated by intracellular sodium 
and membrane depolarization in oligodendrocyte progenitor cells. J. Neurosci. $17,2669-2682$.

Lecca, D., Trincavelli, M. L., Gelosa, P., Sironi, L., Ciana, P., Fumagalli, M., et al. (2008). The recently identified P2Y-like receptor GPR17 is a sensor of brain damage and a new target for brain repair. PLoS One 3:e3579. doi: 10. 1371/journal.pone.0003579

Levi, G., Gallo, V., and Ciotti, M. T. (1986). Bipotential precursors of putative fibrous astrocytes and oligodendrocytes in rat cerebellar cultures express distinct surface features and "neuron-like" gamma-aminobutyric acid transport. Proc. Natl. Acad. Sci. U S A 83, 1504-1508. doi: 10.1073/ pnas.83.5.1504

Levine, J. M., and Reynolds, R. (1999). Activation and proliferation of endogenous oligodendrocyte precursor cells during ethidium bromideinduced demyelination. Exp. Neurol. 160, 333-347. doi: 10.1006/exnr. 1999.7224

Ligon, K. L., Kesari, S., Kitada, M., Sun, T., Arnett, H. A., Alberta, J. A., et al. (2006). Development of NG2 neural progenitor cells requires Olig gene function. Proc. Natl. Acad. Sci. U S A 103, 7853-7858. doi: 10.1073/pnas.0511 001103

Loeliger, M., Inder, T., Cain, S., Ramesh, R. C., Camm, E., Thomson, M. A., et al. (2006). Cerebral outcomes in a preterm baboon model of early versus delayed nasal continuous positive airway pressure. Pediatrics 118, 1640-1653. doi: 10. 1542/peds.2006-0653

Mathew, O. P. (2011). Apnea of prematurity: pathogenesis and management strategies. J. Perinatol. 31, 302-310. doi: 10.1038/jp.2010.126

Melani, A., Cipriani, S., Vannucchi, M. G., Nosi, D., Donati, C., Bruni, P., et al. (2009). Selective adenosine $A_{2 A}$ receptor antagonism reduces JNK activation in oligodendrocytes after cerebral ischaemia. Brain 132, 1480-1495. doi: 10. 1093/brain/awp076

Menn, B., Garcia-Verdugo, J. M., Yaschine, C., Gonzales-Perez, O., Rowitch, D., and Alvarez-Buylla, A. (2006). Origin of oligodendrocytes in the subventricular zone of the adult brain. J. Neurosci. 26, 7907-7918. doi: 10.1523/jneurosci.129906.2006

Ment, L. R., Schwartz, M., Makuch, R. W., and Stewart, W. B. (1998). Association of chronic sublethal hypoxia with ventriculomegaly in the developing rat brain. Brain Res. Dev. Brain Res. 111, 197-203. doi: 10.1016/s0165-3806(98)00139-4

Migita, H., Kominami, K., Higashida, M., Maruyama, R., Tuchida, N., McDonald, F., et al. (2008). Activation of adenosine $A_{1}$ receptor-induced neural stem cell proliferation via MEK/ERK and Akt signaling pathways. J. Neurosci. Res. 86, 2820-2828. doi: $10.1002 /$ jnr.21742

Mills, J. H., Alabanza, L. M., Mahamed, D. A., and Bynoe, M. S. (2012). Extracellular adenosine signaling induces CX3CL1 expression in the brain to promote experimental autoimmune encephalomyelitis. J. Neuroinflammation 9:193. doi: 10.1186/1742-2094-9-193

Mishra, S. K., Braun, N., Shukla, V., Füllgrabe, M., Schomerus, C., Korf, H. W., et al. (2006). Extracellular nucleotide signaling in adult neural stem cells: synergism with growth factor-mediated cellular proliferation. Development 133, 675-684. doi: 10.1242/dev.02233

Nishiyama, A., Chang, A., and Trapp, B. D. (1999). NG2+ glial cells: a novel glial cell population in the adult brain. J. Neuropathol. Exp. Neurol. 58, 1113-1124. doi: 10.1097/00005072-199911000-00001

Nishiyama, A., Komitova, M., Suzuki, R., and Zhu, X. (2009). Polydendrocytes (NG2 cells): multifunctional cells with lineage plasticity. Nat. Rev. Neurosci. 10, 9-22. doi: $10.1038 / \mathrm{nrn} 2495$

Nishiyama, A., Lin, X. M., Giese, N., Heldin, C. H., and Stallcup, W. B. (1996). Interaction between NG2 proteoglycan and PDGF alpha-receptor on O2A progenitor cells is required for optimal response to PDGF. J. Neurosci. Res. 43, 315-330. doi: 10.1002/(sici)1097-4547(19960201)43:3<315:: aid-jnr6>3.0.co;2-m

Nishiyama, A., Watanabe, M., Yang, Z., and Bu, J. (2002). Identity, distribution and development of polydendrocytes: NG2-expressing glial cells. J. Neurocytol. 31, 437-455. doi: 10.1023/A:1025783412651

Ong, W. Y., and Levine, J. M. (1999). A light and electron microscopic study of NG2 chondroitin sulfate proteoglycan-positive oligodendrocyte precursor cells in the normal and kainate-lesioned rat hippocampus. Neuroscience 92, 83-95. doi: 10.1016/s0306-4522(98)00751-9

Othman, T., Yan, H., and Rivkees, S. A. (2003). Oligodendrocytes express functional A1 adenosine receptors that stimulate cellular migration. Glia 44, 166-172. doi: $10.1002 /$ glia. 10281
Pedata, F., Pugliese, A. M., Coppi, E., Dettori, I., Maraula, G., Cellai, L., et al. (2014). Adenosine $\mathrm{A}_{2 \mathrm{~A}}$ receptors modulate acute injury and neuroinflammation in brain ischemia. Mediators. Inflamm. 2014:805198. doi: 10.1155/2014/805198

Pringle, N. P., Mudhar, H. S., Collarini, E. J., and Richardson, W. D. (1992). PDGF receptors in the rat CNS: during late neurogenesis, PDGF alpha-receptor expression appears to be restricted to glial cells of the oligodendrocyte lineage. Development 115, 535-551.

Raff, M. C., Miller, R. H., and Noble, M. (1983). A glial progenitor cell that develops in vitro into an astrocyte or an oligodendrocyte depending on culture medium. Nature 303, 390-396. doi: 10.1038/303390a0

Rissanen, E., Virta, J. R., Paavilainen, T., Tuisku, J., Helin, S., Luoto, P., et al. (2013). Adenosine $A_{2 A}$ receptors in secondary progressive multiple sclerosis: a [(11)C]TMSX brain PET study. J. Cereb. Blood Flow Metab. 339, 1394-1401. doi: $10.1038 / \mathrm{jcbfm} .2013 .85$

Rivers, L. E., Young, K. M., Rizzi, M., Jamen, F., Psachoulia, K., Wade, A., et al. (2008). PDGFRA/NG2 glia generate myelinating oligodendrocytes and piriform projection neurons in adult mice. Nat. Neurosci. 11, 1392-1401. doi: $10.1038 / \mathrm{nn} .2220$

Rivkees, S. A., and Wendler, C. C. (2011). Adverse and protective influences of adenosine on the newborn and embryo: implications for preterm white matter injury and embryo protection. Pediatr. Res. 69, 271-278. doi: 10.1203/pdr. 0b013e31820efbcf

Scolding, N. J., Frith, S., Linington, C., Morgan, B. P., Campbell, A. K., and Compston, D. A. (1989). Myelin-oligodendrocyte glycoprotein (MOG) is a surface marker of oligodendrocyte maturation. J. Neuroimmunol. 22, 169-176. doi: 10.1016/0165-5728(89)90014-3

Shrager, P., and Novakovic, S. D. (1995). Control of myelination, axonal growth and synapse formation in spinal cord explants by ion channels and electrical activity. Brain Res. Dev. Brain Res. 88, 68-78. doi: 10.1016/01653806(95)00081-n

Simon, C., Götz, M., and Dimou, L. (2011). Progenitors in the adult cerebral cortex: cell cycle properties and regulation by physiological stimuli and injury. Glia 59, 869-881. doi: 10.1002/glia.21156

Sitkovsky, M. V., Lukashev, D., Apasov, S., Kojima, H., Koshiba, M., Caldwell, C., et al. (2004). Physiological control of immune response and inflammatory tissue damage by hypoxia-inducible factors and adenosine $\mathrm{A}_{2 \mathrm{~A}}$ receptors. Annu. Rev. Immunol. 22, 657-682. doi: 10.1146/annurev.immunol.22.012703. 104731

Sommer, I., and Schachner, M. (1981). Monoclonal antibodies (O1 to O4) to oligodendrocyte cell surfaces: an immunocytological study in the central nervous system. Dev. Biol. 83, 311-327. doi: 10.1016/0012-1606(81)90477-2

Sontheimer, H., and Kettenmann, H. (1988). Heterogeneity of potassium currents in cultured oligodendrocytes. Glia 1, 415-420. doi: 10.1002/glia.440010609

Sontheimer, H., Trotter, J., Schachner, M., and Kettenmann, H. (1989). Channel expression correlates with differentiation stage during the development of oligodendrocytes from their precursor cells in culture. Neuron 2, 1135-1145. doi: 10.1016/0896-6273(89)90180-3

Stevens, B., and Fields, R. D. (2000). Response of Schwann cells to action potentials in development. Science 287, 2267-2271. doi: 10.1126/science.287.5461.2267

Stevens, B., Porta, S., Haak, L. L., Gallo, V., and Fields, R. D. (2002). Adenosine: a neuron-glial transmitter promoting myelination in the CNS in response to action potentials. Neuron 36, 855-868. doi: 10.1016/S0896-6273(02)01067-X

Szuchet, S., Nielsen, J. A., Lovas, G., Domowicz, M. S., de Velasco, J. M., Maric, D., et al. (2011). The genetic signature of perineuronal oligodendrocytes reveals their unique phenotype. Eur. J. Neurosci. 34, 1906-1922. doi: 10.1111/j.14609568.2011.07922.x

Turner, C. P., Seli, M., Ment, L., Stewart, W., Yan, H., Johansson, B., et al. (2003). $\mathrm{A}_{1}$ adenosine receptors mediate hypoxia-induced ventriculomegaly. Proc. Natl. Acad. Sci. U S A 100, 11718-11722. doi: 10.1073/pnas.1931975100

Turner, C. P., Yan, H., Schwartz, M., Othman, T., and Rivkees, S. A. (2002). A adenosine receptor activation induces ventriculomegaly and white matter loss. Neuroreport 13, 1199-1204. doi: 10.1097/00001756-200207020-00026

Vautier, F., Belachew, S., Chittajallu, R., and Gallo, V. (2004). Shaker-type potassium channel subunits differentially control oligodendrocyte progenitor proliferation. Glia 48, 337-345. doi: 10.1002/glia.20088

Verkhratsky, A. N., Trotter, J., and Kettenmann, H. (1990). Cultured glial precursor cells from mouse cortex express two types of calcium currents. Neurosci. Lett. 112, 194-198. doi: 10.1016/0304-3940(90)90202-k 
Warrington, A. E., and Pfeiffer, S. E. (1992). Proliferation and differentiation of O4+ oligodendrocytes in postnatal rat cerebellum: analysis in unfixed tissue slices using anti-glycolipid antibodies. J. Neurosci. Res. 33, 338-353. doi: 10. 1002/jnr.490330218

Williamson, A. V., Compston, D. A., and Randall, A. D. (1997). Analysis of the ion channel complement of the rat oligodendrocyte progenitor in a commonly studied in vitro preparation. Eur. J. Neurosci. 9, 706-720. doi: 10.1111/j.14609568.1997.tb01419.x

Windrem, M. S., Nunes, M. C., Rashbaum, W. K., Schwartz, T. H., Goodman, R. A., and McKhann, G. 2nd, et al. (2004). Fetal and adult human oligodendrocyte progenitor cell isolates myelinate the congenitally dysmyelinated brain. Nat. Med. 10, 93-97. doi: 10.1038/nm974

$\mathrm{Xu}, \mathrm{L}$., and Enyeart, J. J. (1999). Adenosine inhibits a non-inactivating $\mathrm{K}^{+}$current in bovine adrenal cortical cells by activation of multiple P1 receptors. J. Physiol. 521(Pt. 1), 81-97. doi: 10.1111/j.1469-7793.1999.00081.x

Yao, S. Q., Li, Z. Z., Huang, Q. Y., Li, F., Wang, Z. W., Augusto, E., et al. (2012). Genetic inactivation of the adenosine $\mathrm{A}(2 \mathrm{~A})$ receptor exacerbates brain damage in mice with experimental autoimmune encephalomyelitis. J. Neurochem. 123, 100-112. doi: 10.1111/j.1471-4159.2012.07807.x

Yin, K. J., Kim, G. M., Lee, J. M., He, Y. Y., Xu, J., and Hsu, C. Y. (2005). JNK activation contributes to DP5 induction and apoptosis following traumatic spinal cord injury. Neurobiol. Dis. 20, 881-889. doi: 10.1016/j.nbd.2005.05.026

Young, K. M., Psachoulia, K., Tripathi, R. B., Dunn, S. J., Cossell, L., Attwell, D., et al. (2013). Oligodendrocyte dynamics in the healthy adult CNS: evidence for myelin remodeling. Neuron 77, 873-885. doi: 10.1016/j.neuron.2013. 01.006

Yu, W. P., Collarini, E. J., Pringle, N. P., and Richardson, W. D. (1994). Embryonic exression of myelin genes: evidence for a focal source of oligodendrocyte precursor in the ventricular zone of the neural tube. Neuron 12, 1353-1362. doi: 10.1016/0896-6273(94)90450-2

Zawadzka, M., Rivers, L. E., Fancy, S. P., Zhao, C., Tripathi, R., Jamen, F., et al. (2010). CNS-resident glial progenitor/stem cells produce Schwann cells as well as oligodendrocytes during repair of CNS demyelination. Cell. Stem. Cell 6, 578-590. doi: 10.1016/j.stem.2010.04.002

Zhang, S. C. (2001). Defining glial cells during CNS development. Nat. Rev. Neurosci. 2, 840-843. doi: 10.1038/35097593

Conflict of Interest Statement: The authors declare that the research was conducted in the absence of any commercial or financial relationships that could be construed as a potential conflict of interest.

Copyright (c) 2015 Coppi, Cellai, Maraula, Dettori, Melani, Pugliese and Pedata. This is an open-access article distributed under the terms of the Creative Commons Attribution License (CC BY). The use, distribution and reproduction in other forums is permitted, provided the original author(s) or licensor are credited and that the original publication in this journal is cited, in accordance with accepted academic practice. No use, distribution or reproduction is permitted which does not comply with these terms. 